\title{
Water Quality of the North Banat Basal Aquifer System
}

\section{Milka Vidović ${ }^{1}$ Zoran Nikić ${ }^{2}$, Boban Milovanović ${ }^{3}$}

\begin{abstract}
North Banat, an area of about $2329 \mathrm{~km}^{2}$ administered by six municipalities, is the extreme northeastern part of the Republic of Serbia and located in the southeastern margin of Pannonian depression. Drinking water is supplied under artesian or sub artesian pressure of Lower Pleistocene $\left(\mathrm{Q}_{1}\right)$ or Upper Pliocene $\left(\mathrm{Pl}_{3}\right)$ from confined aquifers. Tapped water-bearing beds in Banat dip from northeast to the south, reaching a depth of some $300 \mathrm{~m}$ at surrounding of Kikinda.

Chemically, these "uncommon" waters are a natural rarity controlled by geological and hydrogeological characters of the water-bearing strata. The quality of water, periodically tested and examined, is discussed in this paper and its chemical composition is interpreted in terms of the regional geology.
\end{abstract}

Key words: ground water, hydrogeology, water quality, North Banat.

IHTM, Scientific Institution, 12 Njegoševa, 11000 Belgrade, E-mail: mivibgd@yahoo. com

2 Faculty of Forestry University of Belgrade, 1Kneza Viseslava, 11030 Belgrade. E-mail: znikic@yubc.net

${ }^{3}$ Galenika a.d., bb Batajnički drum, Zemun

\section{Introduction}

North Banat of about $2329 \mathrm{~km}^{2}$ in area is the northeastern part of the Vojvodina Province that occupies southeastern margine of the Pannonian depression (Fig. 1). An organized public water supply in North Banat began in the sixties of the $2 \mathrm{o}^{\text {th }}$ century. Sources of the domestic and industrial water supplies are confined aquifers about $160 \mathrm{~m}$ to $300 \mathrm{~m}$ deep. The aquifer depth decreases from the NE to the south, being $300 \mathrm{~m}$ at Kikinda.

Water of "uncommon" composition is the only potable water in the semi-arid area of Kikinda. To meet the general demand, it is withdrawn in excess of the natural replenishment that results in continuous reduction of the pressure head. What causes the extraordinary chemical composition of pumped water is probably the character of the water-bearing strata. Reference in formation (Vuković et al., 1979) dates this water between twenty and thirty thousand years ago. Notwithstanding the efforts to find the cause of the uncommon chemical composition of the water, its many explanations are only hypothetical. The quality of confined groundwater is not uniform in the study area. An essential characteristic is the high organic content of natural origin (Čukić et al., 1987, 1994).

Earlier examinations focused only on organic material in the water that could affect its sensory properties (colour, taste and odour). There are few references to the full chemical composition of this water (Vidović, 1996). More light has been thrown on the water quality on the last ten years (Čukić, 1989; Vidović, 1998) through specific explorations for water supply and petroleum and gas resources.

\section{Materials and method}

Interpretation of the given hydrogeological section is based on the available published information and exploratory drilling records for northern Banat (Fig. 2). Water was sampled from pressure pipes of the municipal water supply wells in each season of the year. The analysis covered series of 34-56

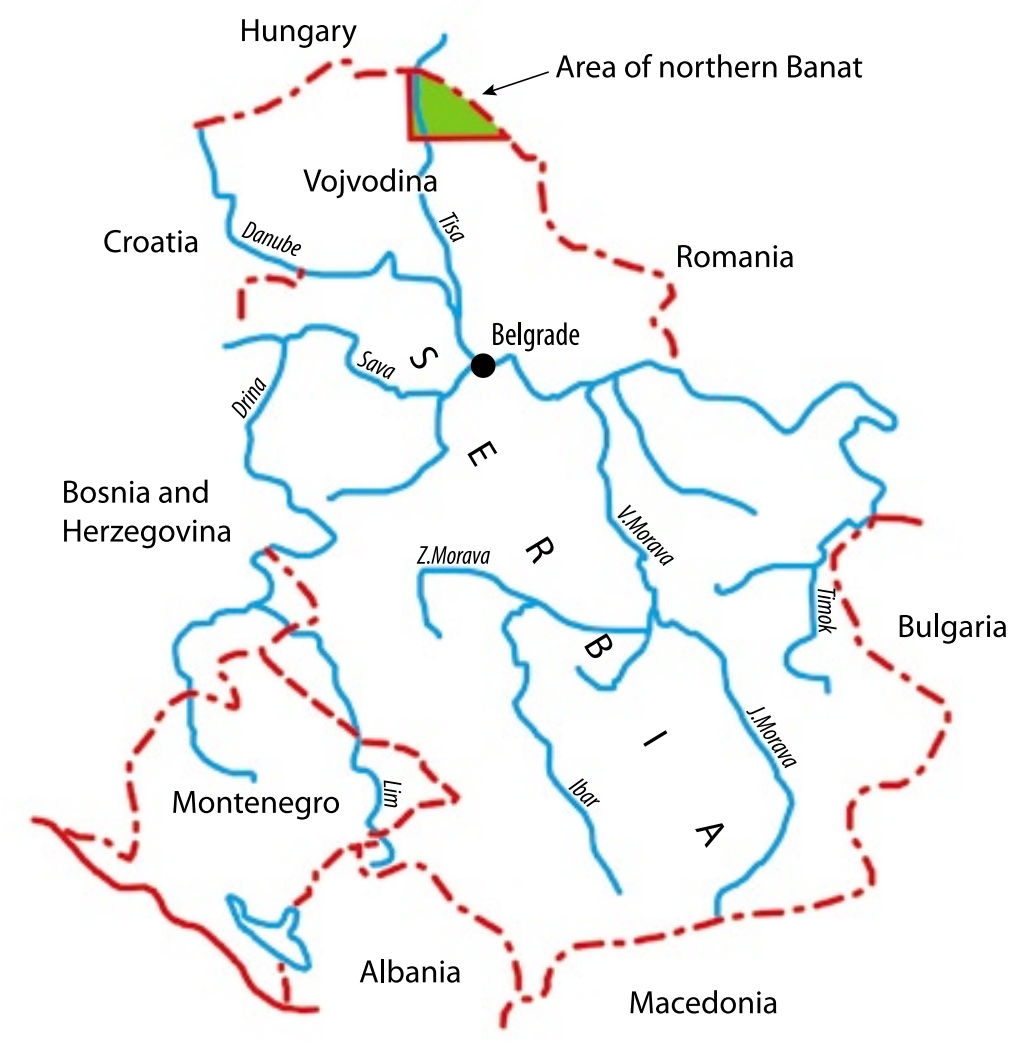

Fig. 1 Geographical location of North Banat 


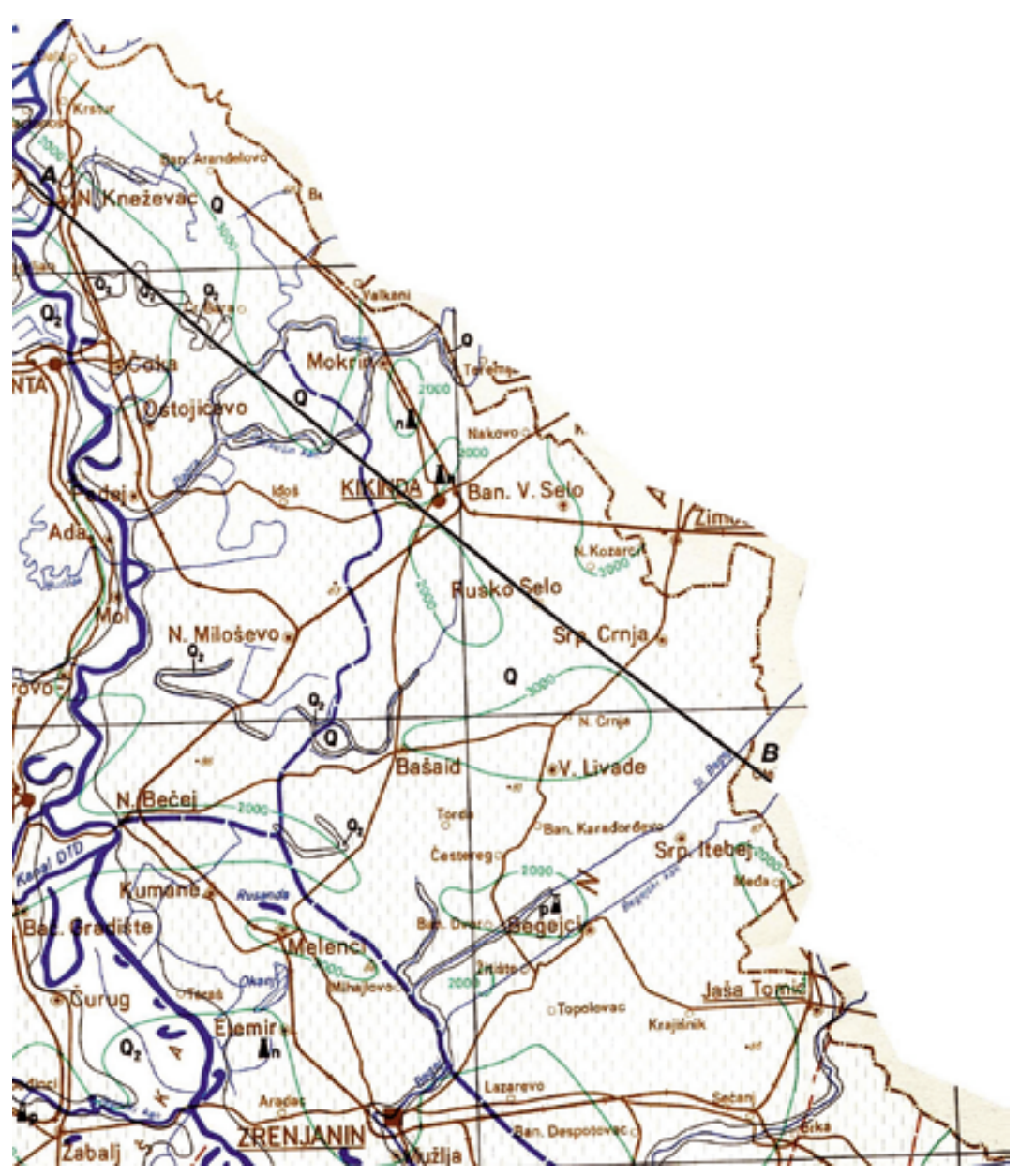

Fig. 2 Geological map of North Banat with indicated investigated section A-B

information for 32 water quality parameters selected to represent best the problem.

Table 1 gives maximum, minimum and average results of the groundwater chemical analyses for Kikinda area, which are commented in the text. Standard and generally accepted examination methods were used (Merek, 1974; US EPA, 1988; APHA, 1989; Škunca-Milovanović et al., 1990).

\section{Results and Discussion}

\section{a) Hydrogeological Properties}

The aquifer tapped for the Kikinda water supply is part of a thick body of sands and sandy clay and clays alternating both horizontally and vertically. Water-bearing horizons are constituents of polycyclic fluvial sediments, fluviatile lake and fluvial sediments of Pleistocene age. Polycyclic sediments are the oldest Quaternary (Pleistocene) deposits unconformable over the upper palustrine beds. The Pliocene/Pleistocene boundary is not identified, only believed to be at a depth of a few hundred metres (Collective authorship, 1976). Generally, its depth decreases southward from the north-northeast Banat, being about 300 $m$ deep in Kikinda area. A basic characteristic of polycyclic fluvial sediments is the sucession of riverbed facies (sands, infrequent gravels) and alluvial facies (silt and clay) as a multiple repetition of complete (gravel- sand-silt-clay) or reduced cycles in several sections A heterogeneous body of permeable material separated laterally and vertically by less permeable or impermeable silty sand, silt or silty clay as a result of deposits' origin acts as a water-yielding hydraulic unit or a basic aquifer system (Collective authorship, 1996). Because the withdrawal is in excess of natural replenishment, the pressure head is continuously reduced.

Polycyclyc fluvial sediments are conformably overlain by fluviatile lake deposits also of Pleistocene age. Major constituents of the fluviatile lake deposits are silt and silt-and-fluviatile clays of alluvial and oxbow facies with intercalations or lenses of dominantly fine sands of the riverbed facies. For explanation of the water quality, an important characteristic of the fluviatile lake deposits is the local occurrence of silt intercalations with remains of the halfbog vegetation up to $5 \mathrm{~m}$ thick (Collective authorship, 1999).

Fluviatile lake deposits are more than $100 \mathrm{~m}$ thick in the Kikinda-Nakovo-Mokrin depression. Lithologic logs for Kikinda show "grey-greenish sandy clay, coal-intercalated" at depths from $223 \mathrm{~m}$ to $261 \mathrm{~m}$. Shallower Pleistocene units contain fluvial and river terrace sediments (sands, silts and clays) of relatively small thickness (about $30 \mathrm{~m}$ ) and thereby of a marginal hydrogeologic importance.

\section{b) Chemical Properties of Water}

Groundwater in the area was examined on chemical and physial properties with the view to its domestic use, not for hydrodynamic or hydrochemical study of the aquifer, groundwater flow or relation between water-bearing horizons.

The examinations confirmed specific water quality characterized by extremely low total hardness $\left(1.7^{\circ} \mathrm{dH}\right)$ and high natural organic content (about $27 \mathrm{mg} / \mathrm{dm}^{3}$ ), which give water the characteristic opalescent pale-yellow colour, both properties very uncomon of ground water.

The obtained properties (Tab. 1) indicate stable quality, increased temperature (about $295 \mathrm{~K}$ ), pH variation within a narrow range (from 8.1 to 8.2), and negative redox potential $(-40 \mathrm{mV})$ from the presence of reductive agents. Water emits 'sulphureous odour' produced by anaerobic processes. The type of water, by its inorganic content, is $\mathrm{Na}^{+} \mathrm{HCO}_{3}{ }^{-}$.

Dominant kation is that of sodium, exceeding the maximum allowed concentration (MAC) for drinking water, whereas calcium and magnesium concentrations are very low whih is rare for ground waters. Concentrations of $\mathrm{Fe}$ and $\mathrm{Mn}$, below MAC for drinking water, are also somewhat unusual for ground water (Yugoslav Regulations 1998).

Hydrocarbonates are dominant anions, followed by silicates, while sulphate, chloride and fluoride concentrations are very low. Ammonia nitrogen is higher than MAC for drinking water, which is common for ground waters. It is interesting to note that organic nitrogen is relatively high, probably incorporated into the structure of humic substances.

In addition to the common free $\mathrm{CO}_{2}$, gaseous constituents are methane and free hydrogen sulphide that give water its nasty smell and taste. The absence of oxygen also effects its sensorial quality. Oligoelements are contained either in traces or below the limit of detection, excluding somewhat higher arsenic $(12 \mu \mathrm{g} / \mathrm{l})$. Total $\beta$-radioactivity also is below the allowed limit.

Concentrations of phenols and mineral oils are very low (at detection limit), and pesticides are undetected, not even in traces. Total polycyclic aromatic hydrocarbons (PAH) is below MAC for potable water.

It should be also noted that fresh ground water is bacteria-free, which was and has been a strong argument for its use despite the evident defects. The argument is irrelevant under the prevailing distribution conditions, because other intricate factors in major distribution systems that conduct water of the given quality generate secondary pollutants. A noteworthy information is also that potential trihalogen methane (dominantly chloroform) varies between 350 and $400 \mu \mathrm{g} / \mathrm{dm}^{3}$. 
Table 1 Maximum, minimum and average results of the groundwater chemical analyses for Kikinda area

\begin{tabular}{|c|c|c|c|c|c|}
\hline Parameter & Unit & $\begin{array}{l}\text { Medium } \\
\text { values }\end{array}$ & $\begin{array}{l}\text { Maximum } \\
\text { values }\end{array}$ & $\begin{array}{l}\text { Minimum } \\
\text { values }\end{array}$ & $\begin{array}{l}\text { Values of drinking water parameters } \\
\text { according to regulations }\end{array}$ \\
\hline Water temperature & K & $295,16^{*}$ & 295,66 & 294,66 & $281,16-285,16$ \\
\hline Odour & - & On sulphide* & On sulphide & On sulphide & Without odour \\
\hline Turbidity & NTU & $1,6^{*}$ & 1,8 & 1,4 & 1,0 \\
\hline Colour & ${ }^{\circ} \mathrm{C}_{0}-\mathrm{Pt}$ & $28,0^{*}$ & 32 & 24 & 5 \\
\hline $\mathrm{pH}$ value & - & 8,2 & 8,2 & 8,1 & $6,8-8,5$ \\
\hline Dry residue $\left(105^{\circ} \mathrm{C}\right)$ & $\mathrm{mg} / \mathrm{dm}^{3}$ & 485 & 550 & 448 & \\
\hline Consumption of $\mathrm{KMnO}_{4}$ & $\mathrm{mg} / \mathrm{dm}^{3}$ & $28,5^{*}$ & 31,0 & 26,8 & 8,0 \\
\hline Dissolved $\mathrm{O}_{2}$ & $\mathrm{mg} / \mathrm{dm}^{3}$ & 0,0 & 0,0 & 0,0 & \\
\hline Conductivity $\left(20^{\circ} \mathrm{C}\right)$ & $\mu \mathrm{S} / \mathrm{cm}$ & 945 & 989 & 791 & do 1000 \\
\hline Redox potential & $\mathrm{mv}$ & -40 & -49 & -31 & \\
\hline Total hardness & $\mathrm{mgCaCO}_{3} / \mathrm{dm}^{3}$ & 28,6 & 30,43 & 26,85 & \\
\hline Total alkality & $\mathrm{mgCaCO}_{3} / \mathrm{dm}^{3}$ & 422,4 & 451,8 & 398,6 & \\
\hline p-alkality & $\mathrm{mgCaCO}_{3} / \mathrm{dm}^{3}$ & 0,0 & 0,0 & 0,0 & 0,0 \\
\hline Free $\mathrm{CO}_{2}$ & $\mathrm{mg} / \mathrm{dm}^{3}$ & 2,5 & 2,6 & 2,3 & \\
\hline $\mathrm{H}_{2} \mathrm{~S}$ (free) & $\mathrm{mg} / \mathrm{dm}^{3}$ & $0,19^{*}$ & 0,20 & 0,17 & bez \\
\hline UV extintion (254nm) & $1 / \mathrm{m}$ & 31,4 & 32,4 & 29,6 & \\
\hline Total a -radioactivity & $\mathrm{Bq} / \mathrm{dm}^{3}$ & 0,087 & 0,088 & 0,085 & 0,1 \\
\hline Total $\beta$-radioactivity & $\mathrm{Bq} / \mathrm{dm}^{3}$ & $<0,037$ & 0,039 & 0,034 & 1,0 \\
\hline $\mathrm{NH}_{3}$ & $\mathrm{mgNH}_{3} / \mathrm{dm}^{3}$ & $0,58^{*}$ & 0,72 & 0,49 & 0,1 \\
\hline $\mathrm{Ca}$ & $\mathrm{mg} / \mathrm{dm}^{3}$ & 10,2 & 12,0 & 8,6 & 200,0 \\
\hline $\mathrm{Mg}$ & $\mathrm{mg} / \mathrm{dm}^{3}$ & 2,74 & 3,1 & 2,4 & 50,0 \\
\hline K & $\mathrm{mg} / \mathrm{dm}^{3}$ & 0,93 & 1,1 & 0,8 & 12,0 \\
\hline $\mathrm{Na}$ & $\mathrm{mg} / \mathrm{dm}^{3}$ & $219^{*}$ & 225 & 205 & 150,0 \\
\hline Fe (total) & $\mathrm{mg} / \mathrm{dm}^{3}$ & 0,12 & 0,18 & 0,09 & 0,3 \\
\hline Mn(total) & $\mathrm{mg} / \mathrm{dm}^{3}$ & 0,03 & 0,04 & 0,02 & 0,05 \\
\hline $\mathrm{Zn}$ & $\mathrm{mg} / \mathrm{dm}^{3}$ & 0,007 & 0,0079 & 0,0064 & 3,0 \\
\hline $\mathrm{Cu}$ & $\mathrm{mg} / \mathrm{dm}^{3}$ & 0,0090 & 0,011 & 0,0083 & 2,0 \\
\hline $\mathrm{Cd}$ & $\mathrm{mg} / \mathrm{dm}^{3}$ & $<0,0001$ & $<0,0001$ & $<0,0001$ & 0,003 \\
\hline $\mathrm{Pb}$ & $\mathrm{mg} / \mathrm{dm}^{3}$ & $<0,002$ & $<0,002$ & $<0,002$ & 0,01 \\
\hline $\mathrm{Ni}$ & $\mathrm{mg} / \mathrm{dm}^{3}$ & $<0,001$ & $<0,001$ & $<0,001$ & 0,02 \\
\hline $\mathrm{Cr}$ (total) & $\mathrm{mg} / \mathrm{dm}^{3}$ & $<0,001$ & $<0,001$ & $<0,001$ & 0,05 \\
\hline As & $\mathrm{mg} / \mathrm{dm}^{3}$ & 0,012 & 0,014 & 0,011 & 0,01 \\
\hline $\mathrm{Hg}$ & $\mathrm{mg} / \mathrm{dm}^{3}$ & $<0,0002$ & $<0,0002$ & $<0,0002$ & 0,001 \\
\hline Nitrates & $\mathrm{mgNO}_{3} / \mathrm{dm}^{3}$ & 0,015 & 0,023 & 0,010 & 50,0 \\
\hline Nitrites & $\mathrm{mgNO}_{2} / \mathrm{dm}^{3}$ & 0,004 & 0,006 & 0,002 & 0,03 \\
\hline Sulphates & $\mathrm{mg} / \mathrm{dm}^{3}$ & 1,12 & 1,18 & 1,09 & 250 \\
\hline Chlorides & $\mathrm{mg} / \mathrm{dm}^{3}$ & 4,45 & 4,60 & 4,21 & 200 \\
\hline Phosphates (orto) & $\mathrm{mgP} / \mathrm{dm}^{3}$ & 0,053 & 0,057 & 0,050 & 0,15 \\
\hline Cyanides & $\mathrm{mg} / \mathrm{dm}^{3}$ & $<0,005$ & $<0,005$ & $<0,005$ & 0,05 \\
\hline Fluorides & $\mathrm{mg} / \mathrm{dm}^{3}$ & 0,5 & 0,6 & 0,4 & 1,2 \\
\hline Silicates & $\mathrm{mg} / \mathrm{dm}^{3}$ & 12,4 & 13,2 & 11,9 & \\
\hline Total organic carbon & $\mathrm{mg} / \mathrm{dm}^{3}$ & 13,2 & 13,8 & 11,2 & - \\
\hline Detergent (anionian) & $\mathrm{mg} / \mathrm{dm}^{3}$ & $<0,005$ & $<0,005$ & $<0,005$ & 0,1 \\
\hline Phenoles (4-A method) & $\mathrm{mg} / \mathrm{dm}^{3}$ & $<0,002$ & $<0,002$ & $<0,002$ & 0,001 \\
\hline Total oils and fats & $\mathrm{mg} / \mathrm{dm}^{3}$ & 0,019 & 0,0199 & 0,0186 & 0,1 \\
\hline Mineral oils & $\mathrm{mg} / \mathrm{dm}^{3}$ & $<0,010$ & $<0,010$ & $<0,010$ & 0,010 \\
\hline \multicolumn{5}{|c|}{ Polycyclic aromatic hydrocarbon } & $\sum 0,0002$ \\
\hline Fluoroanthene & $\mathrm{mg} / \mathrm{dm}^{3}$ & 0,06 & 0,07 & 0,04 & \\
\hline Benzo-3,4fluoroanthene & $\mathrm{mg} / \mathrm{dm}^{3}$ & xnd & & & \\
\hline Benzo 3,4-pyrene & $\mathrm{mg} / \mathrm{dm}^{3}$ & nd & & & 0,00001 \\
\hline Benzo 1,12 perylene & $\mathrm{mg} / \mathrm{dm}^{3}$ & nd & & & \\
\hline Indeno $(1,2,3, \mathrm{~cd})$ pyrene & $\mathrm{mg} / \mathrm{dm}^{3}$ & nd & & & \\
\hline \multicolumn{6}{|c|}{ Halogen Organic Compounds } \\
\hline Chloroform & $\mathrm{mg} / \mathrm{dm}^{3}$ & nd & & & 0,04 \\
\hline Dibromochloromethane & $\mathrm{mg} / \mathrm{dm}^{3}$ & nd & & & 0,0015 \\
\hline Dichlorobromomethane & $\mathrm{mg} / \mathrm{dm}^{3}$ & nd & & & \\
\hline Bromoform & $\mathrm{mg} / \mathrm{dm}^{3}$ & nd & & & \\
\hline
\end{tabular}




\begin{tabular}{|c|c|c|c|c|c|}
\hline Parameter & Unit & $\begin{array}{l}\text { Medium } \\
\text { values }\end{array}$ & $\begin{array}{l}\text { Maximum } \\
\text { values }\end{array}$ & $\begin{array}{l}\text { Minimum } \\
\text { values }\end{array}$ & $\begin{array}{l}\text { Values of drinking water parameters } \\
\text { according to regulations }\end{array}$ \\
\hline 1,2 dichloroethane & $\mathrm{mg} / \mathrm{dm}^{3}$ & nd & & & 0,003 \\
\hline Carbon tetrachloride & $\mathrm{mg} / \mathrm{dm}^{3}$ & nd & & & 0,005 \\
\hline $1,1,1$ trichloroethane & $\mathrm{mg} / \mathrm{dm}^{3}$ & nd & & & 2,0 \\
\hline Trichloroethilene & $\mathrm{mg} / \mathrm{dm}^{3}$ & nd & & & 0,07 \\
\hline Tetrachloroethilene & $\mathrm{mg} / \mathrm{dm}^{3}$ & nd & & & 0,04 \\
\hline \multicolumn{6}{|c|}{ Organic Chlorides Insecticide } \\
\hline Lindan & $\mu \mathrm{g} / \mathrm{dm}^{3}$ & nd & & & 0,2 \\
\hline DDT(DDE+DDT) & $\mu \mathrm{g} / \mathrm{dm}^{3}$ & nd & & & 1,0 \\
\hline Aldrin/ Dieldrin & $\mu \mathrm{g} / \mathrm{dm}^{3}$ & nd & & & 0,03 \\
\hline \multicolumn{6}{|l|}{ Triazine herbicide } \\
\hline Atrazine & $\mu \mathrm{g} / \mathrm{dm}^{3}$ & nd & & & 0,1 \\
\hline Simazine & $\mu \mathrm{g} / \mathrm{dm}^{3}$ & nd & & & 0,1 \\
\hline Prometryn & $\mu \mathrm{g} / \mathrm{dm}^{3}$ & nd & & & 0,1 \\
\hline $\mathrm{PCB}$ & $\mathrm{mg} / \mathrm{dm}^{3}$ & nd & & & 0,0005 \\
\hline
\end{tabular}

${ }^{x}$ nd -no detected exceeding

* -exceeding the maximum allowed concentration

\section{Conclusion}

Geological formations overlying the tapped aquifer in the Kikinda area contain much organic vegetative material. A reasonable assumption is that organic matter in well water originates from the strata containing vegetable irganic material, which existed in the paleoenvironment of marshes.

Beause aquifers of North Banat are the only source of drinking water in this arid district, explorations in the extent of the aquifer that yields water of the described quality may produce information on its origin and provide useful guidelines for selection of the water-treatment technology.

Consumed natural and fresh this water is harmless, but its massive use for domestic supply is questionable under the conditions of its present delivery (mandatory clorination): organic carbon, extremely high in water, allows generation of trihalomethane and other cancerous organochlorine substances which enhance development of microorganisms and saprophytes in the water distribution system.

\section{Acknowledgement}

This work was executed under the basic research programme, Project 146021B: Ge- ological and ecotoxicological research in the identification of geopathogenic zones of toxic elements and natural radioactivity in storage reservoirs for domestic water supply in the Republic of Serbia, funded by the Ministry of Science and Environmental protection of the Serbian Government.

\section{References}

APHA, AWWA, WPCF 1989. Standard Methods for Examination of Water \& Wastewater (18th Ed.).

Colective authorship 1999. Conceptual Design of Water Supply in Vojvodina, Stage Two. Ministry og Agriculture, Forestry and Water Resources, Belgrade.

Collective authorship 1976. Geology of Serbia, Hydrogeology. Belgrade University, Faculty of Mining and Geology.

Collective authorship 1996. Water Management Plan - Draft. Ministry of Agriculture, Forestry and Water Resources, Belgrade.

Čukić, Z. 1987. Kikinda Source Water Quality Examination. "Jaroslav Černi” Institute for Development of Water Resources. Belgrade.

Čukić, Z., Vidović, M., Janać, M., Vulić, D. 1994. Deep Ground Water Quality in

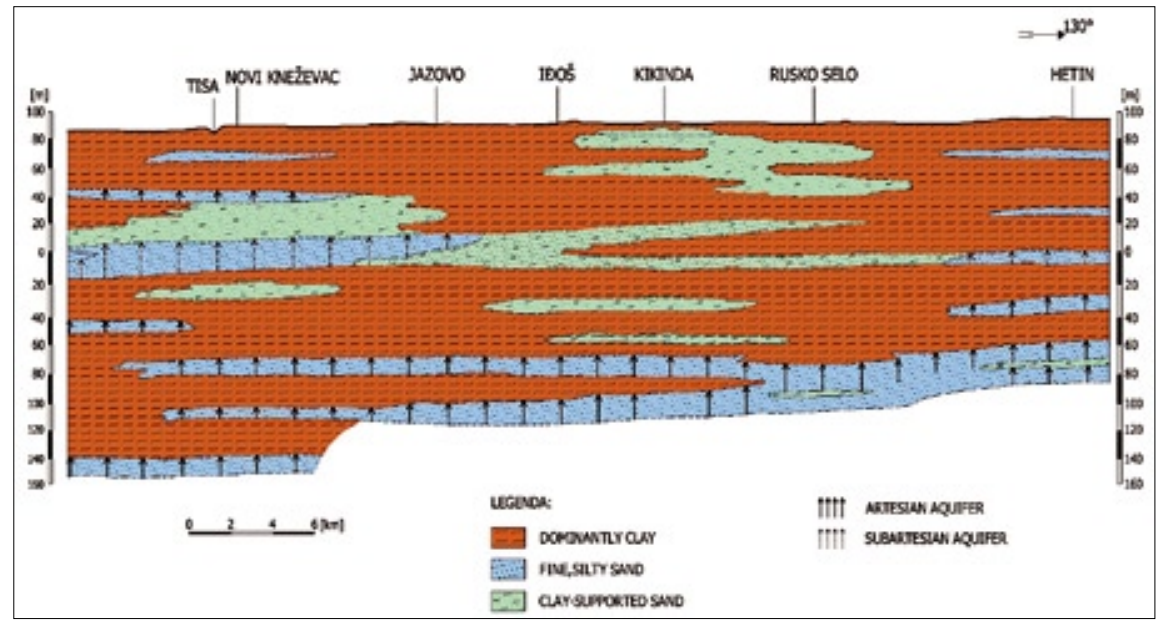

North Banat). Water Quality International Conference Proceedings), Čačak, pp. 69-73.

Čukić, Z., Vidović, M., Perišić, M. 1989. Effects of Water THM Potential Reduction by Mildly Alkaline Macroporous Resins. Water and Sanitation 4, 31-35.

MERCK 1974. The Testing of Water. Darmstadt, Federal Republic of Germany.

"Official Gazette of the Republic of Serbia" no 42/98, Hygienic Standards for Drinking Water.

Škunca-Milovanović, S., Feliks, R., Đurović, B. 1990. Drinking Water, Standard Sanitary Examination Methods. Federal Health Agency. NIP Privredni pregled, Belgade.

US EPA, 1988. Methods for the Determination of Organic Compounds in Drinking Water, 60o/4-88/039, Cincinnati, $\mathrm{OH}, 5-29$.

Vidović, M. 1996. Water Treatment by Adsorption-Removal of Organic Compounds on Macroporous Resins. Master thesis, Novi Sad University, Faculty of Natural Sciences and Mathematics, Novi Sad.

Vidović, M. 1998. Trihalomethane Concentrations and Formational Potential in Humin.Rich Waters. Specialist Thesis. Belgrade University, Faculty of Pharmacy, Belgrade.

Vidović, M. 2002. Heavy Metals in Human Material as a Result of Environmental Pollution, Doctoral Thesis. Faculty of Technology and Metallutgy, Belgrade.

Vuković, M., Pušić, M., Soro, A. 1979. Water Supply to Banat North of the Begej and Old Begej Rivers, Feasibility Study. "Jaroslav Černi" Institute for Development of Water Resources, Belgrade.

Fig. 3 Hydrogeological section A-B (Novi Kneževac-Hetin) 